\title{
Review
}

\section{Carotenoids and Their Biosynthesis in Fungi}

\author{
Gerhard Sandmann
}

Citation: Sandmann, G. Carotenoids and Their Biosynthesis in Fungi.

Molecules 2022, 27, 1431.

https://doi.org/10.3390/

molecules27041431

Academic Editor: Francesco

Cacciola

Received: 26 January 2022

Accepted: 16 February 2022

Published: 21 February 2022

Publisher's Note: MDPI stays neutral with regard to jurisdictional claims in published maps and institutional affiliations.

Copyright: (C) 2022 by the author. Licensee MDPI, Basel, Switzerland. This article is an open access article distributed under the terms and conditions of the Creative Commons Attribution (CC BY) license (https:// creativecommons.org/licenses/by/ $4.0 /)$.
Biosynthesis Group, Institute for Molecular Biosciences, Fachbereich Biowissenschaften, Goethe Universität Frankfurt, D-60438 Frankfurt, Germany; sandmann@bio.uni-frankfurt.de
Abstract: Carotenoids represent a class of pigmented terpenoids. They are distributed in all taxonomic groups of fungi. Most of the fungal carotenoids differ in their chemical structures to those from other organisms. The general function of carotenoids in heterotrophic organisms is protection as antioxidants against reactive oxygen species generated by photosensitized reactions. Furthermore, carotenoids are metabolized to apocarotenoids by oxidative cleavage. This review presents the current knowledge on fungal-specific carotenoids, their occurrence in different taxonomic groups, and their biosynthesis and conversion into trisporic acids. The outline of the different pathways was focused on the reactions and genes involved in not only the known pathways, but also suggested the possible mechanisms of reactions, which may occur in several non-characterized pathways in different fungi. Finally, efforts and strategies for genetic engineering to enhance or establish pathways for the production of various carotenoids in carotenogenic or non-carotenogenic yeasts were highlighted, addressing the most-advanced producers of each engineered yeast, which offered the highest biotechnological potentials as production systems.

Keywords: carotenogenic pathways; carotenoid biosynthesis; carotenoid distribution; carotenoid pathway engineering; reaction mechanisms; trisporic acids

\section{Introduction}

Carotenoids are terpenoid pigments of yellow, orange, and red color. They are synthesized in species from all taxa with the exception of animals [1]. In contrast to photoautotrophic organism, carotenoids are not essential for fungi and are therefore accumulated in much lower concentrations than by plants and algae. However, fungal carotenoids are different to those found elsewhere, offering a structural diversity. In order to increase the levels of commercially interesting carotenoid in different fungal species and to match the concentrations of other organisms, classical and metabolic engineering procedures were established, which will be referred to. Carotenoids are found in all fungal groups along with non-carotenogenic species [2,3]. A general feature of carotenoids is their function as antioxidants. They are able to inactivate oxygen radicals and to quench singlet oxygen [4]. This reactive oxygen species is generated by photosensitized reactions. Protection from cell death caused by light and UV radiation were demonstrated with Microbotryum violaceum (formerly Ustilago violacea) and Neurospora crassa [5,6]. In several fungi, the synthesis of carotenoids is photo-regulated [7]. This light-dependent up-regulation corroborates the importance of antioxidative carotenoids. Another substantial role of carotenoids is their participation in the mating of mucoraceous fungi [8]. More details on the biological functions of carotenoids can be found in reference [9].

First attempts to elucidate the biosynthesis pathway were with mucoraceous fungi. Radioactivity incorporated by feeding acetate and mevalonate, both ${ }^{14} \mathrm{C}$-labelled at different positions [10], were recovered at individual positions of the $\beta$-carotene molecule [11]. The resulting labelling pattern were the first indication leading to the understanding of the reaction sequences in carotenoid biosynthesis. The establishment of the pathway was further substantiated by in vitro incorporation of mevalonate along the carotenoid pathway [12] and with different pigment mutants [13]. 
The review provides an updated knowledge of developments in the fungal carotenoid field. The focus is on the carotenoid structures found in fungi, their biosynthesis pathways, and considerations on the reaction mechanisms for insertion of oxy groups. This also includes distribution of carotenoids within the different fungal groups. Furthermore, the potential of fungi for the production of commercially interesting carotenoids, including their formation by pathway engineering of yeasts, was addressed.

\section{Evolutionary Origin of Fungal Carotenoid Biosynthesis}

As part of the Archaea-Eukarya lineage [14], fungi inherited the potential of carotenoid biosynthesis from archaea. Therefore, carotenoids can be found in species of all fungal phyla. Common to all fungal groups are species which form $\beta$-carotene $[1,2]$ resembling the C40-pathway in the class of Halobacteria [15]. In addition, modifications by oxygenation of $\beta$-carotene and its precursors specifically evolved in fungi. Typical for fungal carotenogenesis is the presence of the $\operatorname{crt} Y B$ fusion gene [16]. It evolved from the co-transcribed overlapping genes of $c r t Y$ and $c r t B$ in Archaea where they are organized in a gene cluster, as exemplified for Sulfolobus solfaticus [17]. Due to the evolutionary relationship with Archaea, fungi inherited the mevalonate pathway from acetyl-CoA for carotenoid precursor synthesis [18] and are devoid of the alternative deoxyxylulose 5-phosphate pathway, which dominates in bacteria [19]. In contrast to the bacterial-chloroplast lineage, fungi did not acquire the formation of an $\varepsilon$-ionone ring, epoxy groups, or 3-hydroxy- $\beta$-ionone end groups (as e.g., in zeaxanthin), with the exception of the astaxanthin pathway in Xanthophyllomyces dendrorhous (see below). In several fungi, carotenoid synthesis is photo-regulated. Transcriptional regulation of carotenoid pathways by light and other factors in Fusarium (formerly Gibberella) fujikuroi, N. crassa [9], and Phycomyces blakesleanus [20] were reviewed.

Along the eukaryotic lineage, animals lost the potential of carotenoid biosynthesis. However, in aphids, such as varieties of Acyrthosiphon pisum, the synthesis of torulene, which is a typical fungal carotenoid, was discovered [21]. Since the crtYB gene, which can be regarded as a fungal signature, is present and involved in aphid carotenoid biosynthesis, it is obvious that this pathway was acquired by horizontal gene transfer from fungi.

\subsection{The Basic Pathway to $\beta$-Carotene}

In $\beta$-carotene synthesizing fungi, the pathway proceeds in three steps (Figure 1). After the condensation of two molecules of geranylgeranyl pyrophosphate to phytoene, a single enzyme catalyzed four desaturation steps. Finally, both enzymes were cyclized to $\beta$-ionone groups. Only two genes encode the enzymes involved: a phytoene synthase lycopene-cyclase fusion gene assigned as al-2, $\operatorname{crt} Y B$, or $\operatorname{car} R A[16,22,23]$ depending on the fungal species, and a phytoene desaturase gene assigned as al-1, crtI, or carB [23-25]. The al-2 gene was first cloned from $N$. crassa as a phytoene synthase gene. For the homolog $\operatorname{crt} Y B$ from $X$. dendrorhous, functional analysis revealed that the expressed gene product catalyzed not only phytoene synthesis, but also lycopene cyclization. Both functional domains could be located in the gene sequence [16]. Both domains were heterologously expressed, and antisera were raised against both proteins. With their help, an individual soluble phytoene synthase domain and an individual membrane-bound lycopene cyclase were detected in Blakeslea trispora, indicating a posttranslational protein cleavage [26]. The first fungal phytoene desaturase gene al-1 was also cloned from N. crassa [24]. Depending on the classification of the carotenogenic species, the desaturases differ in their productspecificity. Corresponding to the synthesis of $\beta$-carotene in fungi from Mucorales, $\operatorname{car} B$ from P. blakesleanus encodes a 4-step desaturase which produces lycopene, as demonstrated by heterologous expression [27] and by lycopene accumulation in the mutant C9 [13]. In contrast, the gene product al-1 from N. crassa inserts a fifth double bond at C3-C4 [28]. This prevents the cyclisation of this further desaturated end of the molecule, and only a single cyclisation step to torulene is possible (Figure 1 right branch). 


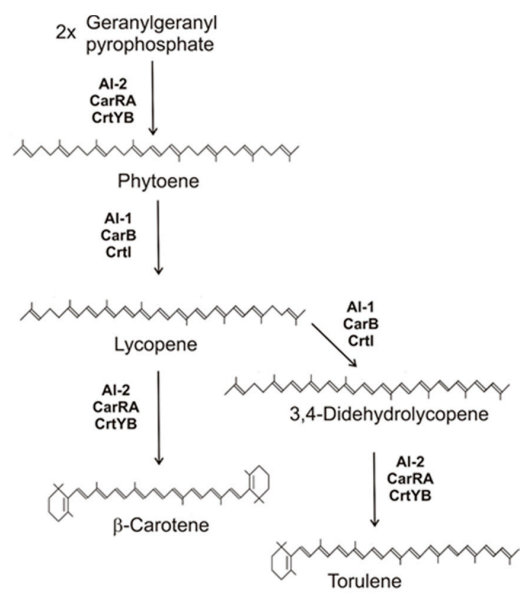

Figure 1. Carotenoid biosynthesis pathway of fungi to $\beta$-carotene and torulene with gene products involved.

\subsection{Synthesis of Neurosporaxanthin in Sordariomycetes}

The end product of carotenoid synthesis of Sordariomycetes is neurosporaxanthin. Its structure was elucidated from $N$. crass $a$ as $4^{\prime}$-apo- $\beta, \psi$-caroten- $4^{\prime}$-oate [29]. Other accumulating intermediates include 3,4-didehydrolycopene and $\gamma$-carotene $[30,31]$. The subsequent pathway steps leading to this C35-apocarotenoid were established for N. crassa based on the genes involved and the carotenoid composition of the yellow YLO mutants. Carotenoids in different YLO strains were identified as apo- $4^{\prime}$-lycopenal and $\beta$-apo- $4^{\prime}$ - carotenal [32] or their derivatives, which were reduced and esterified with fatty acids for better sequestration [31]. These carotenoids in the YLO mutants are the products of the cleavage of the C3-C4 double bond either of 3,4-didehydrolycopene or torulene. Consequently, alternative reaction sequences involved in the late steps to neurosporaxanthin were proposed [31,32]. In carotenoid biosynthesis, enzymes recognize only a certain specific part of the molecule for catalysis. Therefore, different successions of reactions can result in a complex pathway pattern. Based on this and on the data from the above publications, a combined pathway for the late steps in neurosporaxanthin synthesis is presented in Figure 2. The three enzymes involved in parallel reaction sequences are a cyclase recognizing as substrate the $\psi$-end of a carotenoid, a cleavage enzyme splitting the $\mathrm{C} 3-\mathrm{C} 4$ double bond and a $\mathrm{C} 4^{\prime}$-aldehyde oxidase. Starting with the cleavage reactions of 3,4-didehydrolycopene to apo- $4^{\prime}$-lycopenal, this aldehyde is differently metabolized either by cyclization to $\beta$-apo- $4^{\prime}$-carotenal or hydroxylation to $\beta$-apo- $4^{\prime}$-carotenoic acid. As illustrated in Figure 2, left branch, the apo- $4^{\prime}$-lycopenoic acid is cyclized to neurosporaxanthin. Alternatively, 3,4-didehydrolycopene was cyclized to torulene, which was also a substrate for the cleavage reaction (Figure 2, right branch). This directly resulted in the formation of $\beta$-apo- $4^{\prime}$-carotenal, which was further hydroxylated to neurosporaxanthin. Genes involved in these late steps specific to Sordariomycetes are the cleavage enzyme encoded by the cao-2 gene of $N$. crassa [33], also assigned as carT in the genus Fusarium [34], and the aldehyde dehydrogenase gene ylo-1 from N. crassa [32] (as carD in Fusarium) [35]. For the neurosporaxanthin pathways of F. fujikuroi [23], Gibberella zeae [36], and Podospora anserina [37], only the branch via torulene cleavage to $\beta$-apo- $4^{\prime}$-carotenal (Figure 2a, right branch) has been recognized.

\subsection{Synthesis of Astaxanthin in Xanthophyllomyces denrorhous}

The basidiomycetous yeast $X$. denrorhous (anamorph Phaffia rhodozyma) is the only fungus which is able to synthesize the 3,3'-dihydroxy-4, $4^{\prime}$-diketo $\beta$-carotene derivative astaxanthin [38]. Astaxanthin is accumulated as the $3,3^{\prime} \mathrm{R}$ enantiomer in contrast to the $3,3^{\prime}$ S enantiomer synthesized by bacteria [39]. As outlined in Figure 1, the pathway to $\beta$-carotene is catalyzed by the genes indicated in this figure. The complete modification of $\beta$-carotene to astaxanthin, as illustrated in Figure 3, is catalyzed by the product of the asy gene [40], also named crtS in another publication [41]. This unique gene is absent in 
other organisms [40]. The encoded astaxanthin synthase is a P450 monooxygenase that interacts with the $c r t R$ encoded cytochrome P450 reductase [42]. The reaction mechanism of $\beta$-carotene modification by this P450 enzyme involved a series of hydroxylation steps at each $\beta$-ionone ring, forming a keto group after water elimination twice at $C 4$, and then followed by hydroxylation of C3 [40]. The same reactions proceed at $C 3^{\prime}$ and $C 4^{\prime}$ at the other end. All the carotenoids formed by these hydroxylation reactions, the mono-ketolated echinenone, its 3-hydroxy derivative, and phoenicoxanthin which additionally carries a C4' keto group could be identified as intermediates [38]. Another minor carotenoid of $X$. denrorhous is 3-HO-4-ketotorulene. Its synthesis diverts from the main pathway by a fifth desaturation of lycopene to 3,4,-didehydrolycopene in competition to lycopene cyclization (Figure 3, right branch). The concentration of 3-HO-4-ketotorulene below 1\% of total carotenoids in X. dendrorhous [38] may indicate a substantial lower affinity of the desaturase than the cyclase for lycopene. In addition, metabolic engineering also showed that the ratio of lycopene cyclase to phytoene desaturase determined the ratio of $\beta$-carotene versus 3,4,-didehydrolycopene formation [43]. Changes in the gene expression of these competing enzymes may be the reason why different physiological conditions can increase the flux into the monocyclic branch [44]. Finally, 3,4,-didehydrolycopene was cyclized to torulene, into which astaxanthin synthase inserts 3-hydroxy and the 4-keto groups (Figure 3, right branch).



Figure 2. Late steps to neurosporaxanthin in Neurospora crassa, with corresponding fungal gene products.

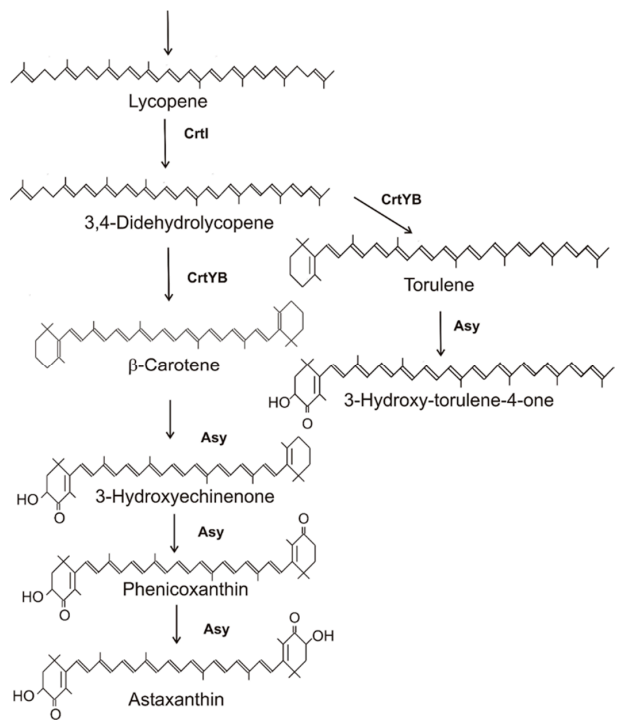

Figure 3. Biosynthesis pathway and gene products for astaxanthin biosynthesis in Xanthophyllomyces dendrorhous. 


\section{Formation of Carotenoid Structures and Their Distribution in Fungi}

Table 1 gives an overview on the distribution of carotenoids in different fungal groups. Most of the carotenoids of this table were only structurally analyzed and identified without the determination of their concentrations. Only for a few species, the concentrations of their specific carotenoids were quantified. Their values range from 100 to $200 \mu \mathrm{g} / \mathrm{g} \mathrm{dw}$ or were even lower $[20,31,45-47]$. The accumulating carotenoid in lower fungi, in the Chytridiomycota and Blastocladiomycota, is the monocyclic $\gamma$-carotene in Table 1. Its synthesis was due to a modified lycopene cyclase which catalyzed formation of only one ionone ring instead of two, as in the case of $\beta$-carotene formation. The bicyclic $\beta$-carotene is typical for species of the Mucoraceae. It was also found as the end product in a few other fungi of Ascomycota and Basidiomycota, but most carotenoids in both phyla were oxygenated derivatives (Figure 4). These oxy carotenoids were derived from acyclic or cyclic carotenes with a polyene system of at least 11 double bonds, and were synthesized as illustrated in Figure 1. Apart from the pathways to $\beta$-carotene, neurosporaxanthin, and astaxanthin (see Section 2), participating genes have not been identified yet and the enzymes involved in their synthesis are not known. Nevertheless, conceivable reaction mechanisms for the insertion of oxy groups into carotenoid molecules can be anticipated in analogy to those identified in bacterial carotenogenesis.

Table 1. Fungal carotenoids and their direct carotene precursors in selected species.

\begin{tabular}{|c|c|c|}
\hline Carotenoids & Selected Species & References \\
\hline Lycopene $\longrightarrow$ & Chytridiomycota: & \\
\hline \multirow[t]{3}{*}{$\gamma$-Carotene } & Cladochytrium replicatum & [2] \\
\hline & Blastocladiomycota & [2] \\
\hline & Allomyces arbuscula & \\
\hline \multirow{8}{*}{$\begin{array}{c}\text { Lycopene }- \text {-Carotene } \\
\beta\end{array}$} & Mucoromycotina: & [1] \\
\hline & Blakeslea trispora & \\
\hline & Phycomyces blakesleanus & \\
\hline & Ascomycota: & [48] \\
\hline & Protomyces inundates & \\
\hline & Basidiomycota: & [49] \\
\hline & Tremella mesenterica & [50] \\
\hline & Gymnosporangium juniperi-virginianae & \\
\hline Lycopene $\rightarrow$ & Ascomycota: & \\
\hline Phillipsiaxanthin & Phillipsia carminea & [2] \\
\hline$\beta$-Carotene $\longrightarrow$ & Basidiomycota: & \\
\hline Canthaxanthin & Cantharellus species & {$[51]$} \\
\hline$\beta$-Carotene $\longrightarrow$ & Basidiomycota: & \\
\hline Astaxanthin & Xanthophyllomyces dendrorhous & [38] \\
\hline$\gamma$-Carotene $\longrightarrow$ & Ascomycota: & \\
\hline \multirow[t]{2}{*}{ Aleuriaxanthin } & Aleuria aurantiaca & [52] \\
\hline & Scutellina umbrarum & [45] \\
\hline \multirow{3}{*}{$\begin{array}{l}\gamma \text {-Carotene and/or torulene } \\
\longrightarrow \text { Neurosporaxanthin }\end{array}$} & Ascomycota: & \\
\hline & Fusarium species & [23] \\
\hline & Neurospora crassa & {$[30]$} \\
\hline \multirow{6}{*}{$\begin{array}{c}\gamma \text {-Carotene and / or torulene } \longrightarrow \\
\text { Plectaniaxanthin and } \\
\text { 2'-didehyroplectaniaxanthin }\end{array}$} & Ascomycota: & \\
\hline & Plectania coccinea & [53] \\
\hline & Sarcoscypha coccinea & [54] \\
\hline & Basidiomycota: & \\
\hline & Cryptococcus laurentii & [55] \\
\hline & Dioszegia species & [46] \\
\hline & Ascomycota: & {$[56]$} \\
\hline \multirow{4}{*}{ Torularhodin } & Cookeina sulcipes & \\
\hline & Basidiomycota: & [57] \\
\hline & Cystofilobasidium species & {$[47]$} \\
\hline & Rhodotorula glutinis & \\
\hline
\end{tabular}




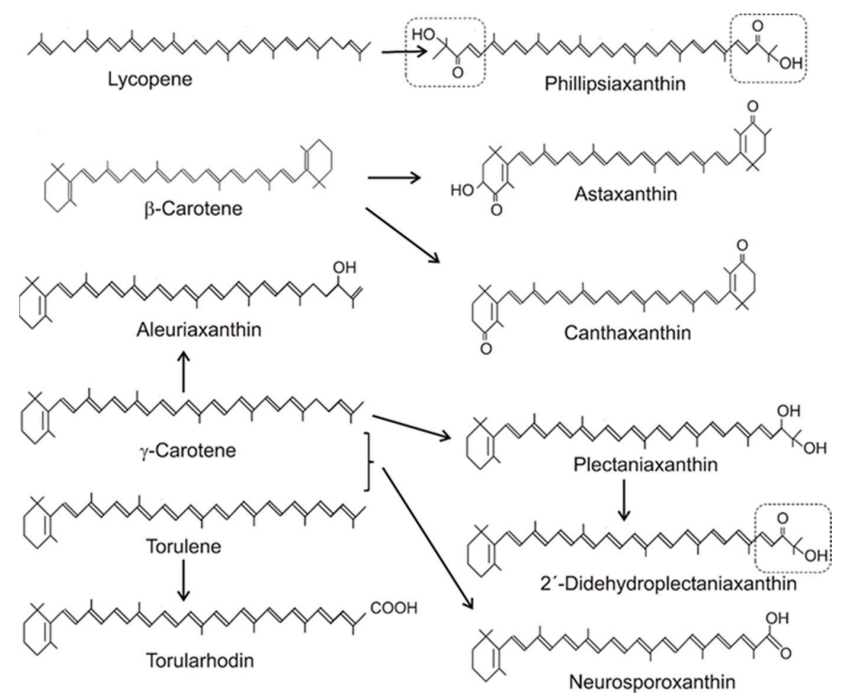

Figure 4. Precursors and structures of oxygenated fungal carotenoids. Identical $3^{\prime} 4^{\prime}$-didehydro- $1^{\prime}, 2^{\prime}$ dihydro- $1^{\prime}$-hydroxy-2'-one- $\psi$-end groups of different carotenoids are boxed.

The $\mathrm{C} 4 / \mathrm{C} 4$ '-diketo $\beta$-carotene derivative canthaxanthin was reported for only one genus, the basidiomycete Cantharellus [51]. Three different reaction types for ketolation occurred in other species. The keto groups may originate from one of them. They include a P450 oxygenase Asy as in X. dendrorhous, or as in different bacteria, either a dioxygenase $\mathrm{CrtW}$ [58] or a CrtI-related ketolase $\mathrm{CrtO}$ forming an allylic carbocation by hydride transfer which reacts with a hydroxyl ion [59]. Finally, the keto group results from a second hydroxylation reaction including water elimination. Phillipsiaxanthin and 2'didehydroplectaniaxanthin of Ascomycota and Basidiomycota share the same $\mathrm{C1}^{\prime}$-hydroxy and $\mathrm{C2}^{\prime}$-keto groups at the acyclic ends of the molecules (Figure 4, boxed region). Similarly to other hydroxylated fungal carotenoids, a certain amount was esterified with fatty acids. Their substitution pattern resembled the 3,4-didehydro acyclic end of demethylspheroidenone from the bacterium Rhodobaca bogoriensis grown under aerobic conditions [60] and may originate from similar reactions: The 1-OH group in this and other purple non-sulphur bacteria were formed by water addition to the $\mathrm{C} 1 / \mathrm{C} 2$ double bond catalyzed by the $\mathrm{crt} C$ gene product (Figure $5 \mathrm{a}$ ). This involved formation of a carbocation at $\mathrm{C} 1$ by protonation of this double bond, followed by its reaction with a hydroxyl ion [61]. In the following steps, a double bond was inserted at $\mathrm{C} 3 / \mathrm{C} 4$ by CrtI-related CrtD [62], and the allylic C2 was ketolated by the monooxygenase $\mathrm{CrtA}$ in two hydroxylation steps with water elimination [63], as shown in Figure 5a. In plectaniaxanthin, this C2 carried a hydroxy instead of the keto group (Figure 4) due to a missing second step, indicating that this carotenoid is the precursor of 2'-didehydroplectaniaxanthin. It is difficult to decide whether torulene or $\gamma$-carotene was the original substrate for the hydroxylations. In the latter case, the biosynthesis of plectaniaxanthin could resemble its formation in the pathway to myxol in cyanobacteria [64]. Torularhodin, which is present in Cookeina sulcipes of Ascomycota and basidiomycetous red yeasts (Table 1), is an oxidation product of torulene with a C16' carboxylic group (Figure 4). Unlike the carboxylic group of neurosporaxanthin, in which the keto moiety is formed by a cleavage oxygenase, a different reaction must be involved in torula-rhodin formation. An alternative method for generation of a carboxylic group at a terminal C-atom is known for 4,4'-diapolycopen-4-oate from Bacillus species [65]. The products of two $c r t I$-related genes, $c r t N b$ and $c r t N c$, first catalyzed the formation of a keto group by double hydroxylation and water elimination, followed by insertion of a hydroxy group (Figure 5b). Another C2'-hydroxy carotenoid, aleuriaxanthin from Aleuria aurantia (Table 1), is unique due to its terminal C16' methylene group (Figure 4). The most likely reaction mechanism for its formation from $\gamma$-carotene starts with hydride transfer from 
$\mathrm{C} 16^{\prime}$ to a cofactor, followed by a mesomeric shift of the $\mathrm{C}^{\prime} / \mathrm{C} 2^{\prime}$ double bond to $\mathrm{C} 1^{\prime} / \mathrm{C} 16^{\prime}$ (Figure 5c). Finally, the resulting $\mathrm{C} 2^{\prime}$ carbocation reacted with a hydroxyl anion.



$$
\text { (1) }
$$



Figure 5. Proposed reaction mechanisms for the modification of acyclic end groups of fungal carotenoids leading to the formation of a $3^{\prime} 4^{\prime}$-didehydro- $1^{\prime}, 2^{\prime}$-dihydro- $1^{\prime}$-hydroxy-2' -one $\psi$-end group (A), carboxylic acid (B) and allylic $1^{\prime}, 2^{\prime}$-dihydro- $1^{\prime}, 16^{\prime}$-didehydro $2^{\prime}$-ol (C). $\mathrm{R}$ indicates the carotenoid residue from six ionone terpenoid building blocks.

Most of the suggested reactions for oxygenation of the carotenoid skeleton in fungi were catalyzed by products of the crtI-gene family. In all cases, the first step was hydride transfer to oxidized FAD as a co-substrate. In the following step, the generated allylic carbocation was stabilized by different reactions, either proton loss forming a double bond or reaction with a hydroxyl ion to an alcohol, and in repetition of this step, to an aldehyde, and further on to an acid [66]. These mechanisms well resemble corresponding pathways in bacteria. Since the bacterial lineage is independent from the fungal one, analogous pathways may have evolved by convergent evolution. Since the CrtI phytoene desaturase was present in all carotenogenic fungi, crtI-derived genes could have diverged independently in fungi as well and acquired a modified novel function similar to bacteria. Alternatively, it is possible that genes encoding these bacterial enzymes have been acquired by horizontal transfer from bacteria. This process plays a significant role in fungal evolution [67].

\section{Conversion of $\beta$-Carotene to Trisporic Acid in the Mucorales}

Trisporic acids were first recognized by their stimulation of $\beta$-carotene synthesis in fungi from the order Mucorales. However, the significant function is the recognition of opposite mating types in heterothallic species for the initiation of zygospore formation. A comprehensive review on the early developments, the significance of trisporic acids, the role in communication between strains, their structures, and their origin from $\beta$-carotene as precursor can be found in reference [68]. Different trisporic acids and their precursors with slight chemical modifications have been identified since then [69]. The structures of the B and $C$ types of trisporic acids first identified from B. trispora [70] are shown in Figure 6 with the exemplified biosynthesis pathway to trisporic acid B [8]. It starts from $\beta$-carotene by two successive cleavage reactions [71]. The products of the gene tsp3 from Rhizopus oryzae [72] or carS from P. blakesleeanus [73] cleave $\beta$-carotene at the C11'-C12' double bond to $\beta$-apo- $12^{\prime}$-carotenal in the initial reaction. The next cleavage step at the C13-C14 double bond by AcaA [73] leads to $\beta$-apo-13-carotenone, the C18 backbone of trisporoids. The following reactions to 4-dihydrotrisporin involve 4-hydroxylation and the saturation of the C11-C12 double bond (Figure 6A). For both reactions, the mechanisms 
have not been defined yet. The hydroxylation of the ionone ring may proceed via one of the steps described for 4-ketolation to canthaxanthin in Section 3. A saturation reaction is very unusual for carotenoids or related compounds. This hydrogenation of C11-C12 shortens the polyene system and isolates the terminal keto group.

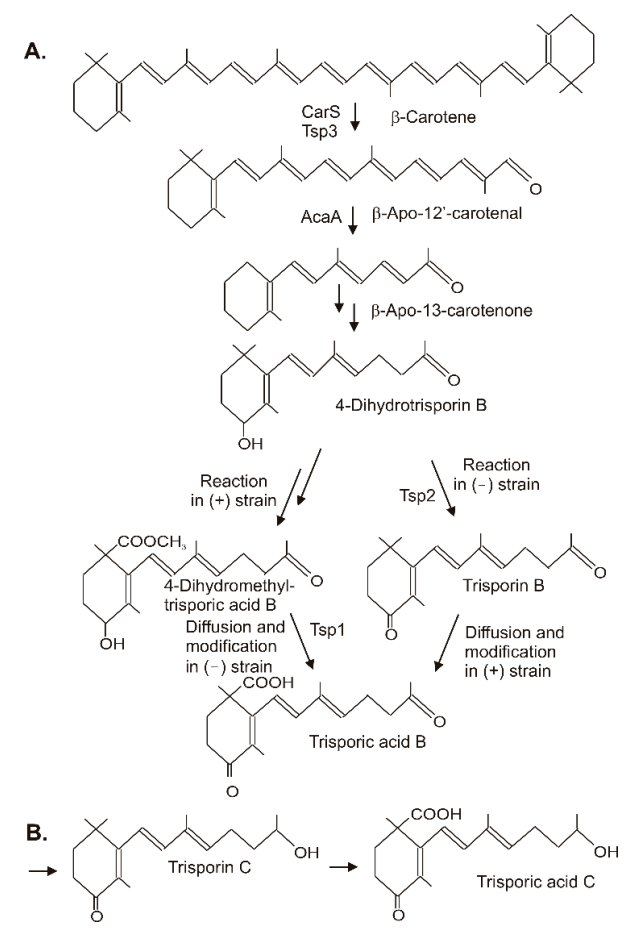

Figure 6. Synthesis of trisporic acids from $\beta$-carotene by interactions of different mating types in Mucoraceae. (A) Pathway to trisporic acid B; (B) Final step in trisporic acid C formation.

The residual pathway continuing with the metabolization of 4-dihydrotrisporin relies on chemical interactions between the two mating partners [74]. Individual steps were catalyzed exclusively either by the $(+)$ or the $(-)$ strain. For pathway continuation, the reaction products from one strain must reach the other by diffusion. This metabolite exchange was necessary for the completion of the pathway to the trisporic acid end product. A 4-dihydrotrisporate dehydrogenase encoded by tsp 2 was active in the (-) strain in the formation of trisporin [75]. It was upregulated in the $(-)$ strain upon mating, but not in the $(+)$ strain. Alternatively, the $(+)$ strain exclusively converts 4 -dihydrotrisporin to the $\mathrm{C} 15$ carboxylic acid, and further on to its methyl ester in B. trispora [76] (Figure 6). Obviously, this ester was transferred to the $(-)$ mating partner where it was oxidized at $C 4$ by NADP-dependent 4-dihydromethyltrisporate aldo/keto reductase, which was isolated from Mucor mucedo as the product of the $t s p 1$ gene [77], and de-esterified to trisporic acid by a (-) strain-specific esterase [78]. In the (+) strain, trisporic acid finally accumulated from carboxylation of trisporin, which was taken up by diffusion from the $(-)$ strain. The carboxylation reaction of the trisporins was not characterized. A possible mechanism may be similar to the carboxylation of a terminal C-atom in the synthesis of torularhodin (Section 3). In the closely related pathway to trisporic acid D, C4 was further oxidized to a keto group, whereas the keto group at C13 was reduced (Figure 6B). The trisporic acids exert a positive feedback on their synthesis and on the carotenoid pathway by transcriptional up-regulation of the pathway genes [69].

\section{High-Yield Carotenoid Production}

Fungi are promising candidates for the production of carotenoids. These pigments are of commercial interest: $\beta$-carotene, as provitamin $A$; astaxanthin, as an antioxidant; and zeaxanthin together with lutein, as protectants of the retina in the eye [79]. In addi- 
tion, substantial amounts of astaxanthin and $\beta$-carotene were applied as feed additives. Carotenogenic fungi can be used best as a carotenoid source after mutagenesis and selection for over-producing strains. Alternatively, non-carotenogenic fungi are appropriate hosts for the design and engineering of carotenoid pathways [80]. Modification examples are outlined in Figure 7, with a focus on the initial highest carotenoid yields under laboratory conditions for comparison of the biosynthesis potential of the transformants. These strategies are advantageous for the generation of strains which are able to accumulate carotenoids comparable other organisms.

A.



B.

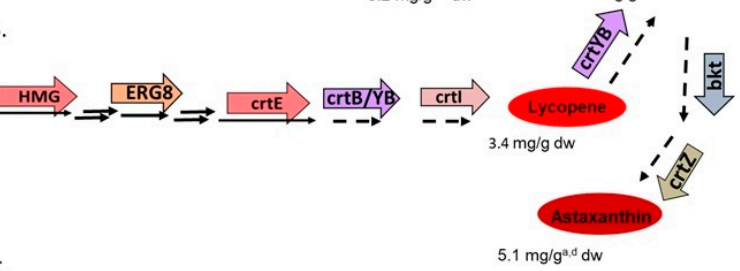

C.



$27.1 \mathrm{mg} / \mathrm{g} \mathrm{dw}$

D.

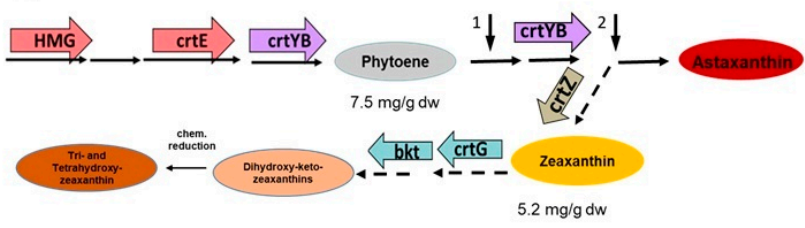

Figure 7. Selected examples of genetic engineering of carotenoids with highest yields in flask cultures on basic medium of different non-conventional yeasts by expression of existing genes, or genes for novel pathway (indicated as dotted arrows). (A) Lipomyces starkeyi [80] or Candida utilis [81,82] or Pichia pastoris [83,84]. (B) Yarrowia lipolytica [85-88]. (C) Rhodotorula utilis [89]. (D) Xanthophyllomyces dendrorhous [90-92]. The chosen uniform assignment of genes of same function also stands for corresponding fungal genes, as listed in Figure 1. Vertical arrow 1 marks inactivation of the phytoene desaturase gene; vertical arrow 2 , inactivation of the astaxanthin synthase gene. ${ }^{\text {a }}$ without gene $H M G$; ${ }^{\mathrm{b}}$ without $\operatorname{crt} E$; $^{\mathrm{c}}$ without squalene synthase inactivation; ${ }^{\mathrm{d}}$ without $E R G 8$ gene.

\subsection{Classical Strain Development by Mutagenesis and Selection for Enhanced Carotenoid Production}

Mutagenesis for alteration of the carotenoid pathway including the generation of high-yield strains was first successfully carried out with P. blakesleeanus [93]. The carS-type mutants obtained by chemical mutagenesis accumulated up to $5.1 \mathrm{mg} / \mathrm{g} \mathrm{dw}$, which is more than 100-fold the amount of $\beta$-carotene in the wild type. A similar type of mutation was obtained with F. fujikuroi, which resulted in increased neurosporaxanthin formation [94]. Considerable attempts were made to mutagenize $X$. denrorhous for enhanced astaxanthin production. This involved mutagenesis by chemicals, low-energy ion beam, or low-dose gamma irradiation [95]. Several rounds of nitrosoguanindin treatment resulted in a mutant with the high astaxanthin content of $1.6 \mathrm{mg} / \mathrm{g} \mathrm{dw}$ [96]. An established industrial process for $\beta$-carotene production uses $B$. trispora and involves co-cultivation of $(+)$ and $(-)$ strains. Highest yields of $39 \mathrm{mg} / \mathrm{g} \mathrm{dw}$ were obtained with improved mutants or inter- 
sexual heterokaryons with nuclei of both mating types [97]. The same strains can be used alternatively for the production of lycopene by application of a lycopene cyclase inhibitor. $\beta$-Carotene production with $B$. trispora is at the moment the only large-scale industrial process for fungal carotenoids. This carotenoid was recovered by extraction and supplied in a crystalline form as a colorant or as provitamin A [79].

\subsection{Metabolic Engineering of Carotenoid Pathways in Non-Conventional Yeasts}

Different non-carotenogenic yeasts were genetically engineered for carotenoid biosynthesis [80]. This started with the transformation of Candida utilis with bacterial genes to establish the pathway to astaxanthin. The genes used were $\operatorname{crt} B$ for phytoene synthesis, crtI for phytoene desaturation to lycopene, $\operatorname{crt} Y$ for cyclisation to $\beta$-carotene, and $\operatorname{crt} W$ together with $\mathrm{crt} Z$ for $\beta$-carotene ketolation and hydroxylation to astaxanthin (Figure 7A), which yielded $0.4 \mathrm{mg} / \mathrm{g}$ dry weight of astaxanthin [81]. The next-generation of recombinant $C$. utilis strains were modified in key metabolic steps by over expression of the gene for HMG-CoA reductase, HMG, which is the limiting enzyme for the entire terpenoid pathway [82]. In addition, one of two alleles of the squalene synthase gene was inactivated together with over expression of the geranylgeranyl pyrophosphate synthase gene $\operatorname{crt} E$ to re-direct metabolite flow from the sterol pathway into carotenoids (Figure 7A). This resulted in an increase of lycopene to $7.8 \mathrm{mg} / \mathrm{g} \mathrm{dw}$. A similar genetic modification of the pathway to lycopene without inactivation of the squalene synthase gene was carried out in a similar way with Lipomyces starkeyi [80] and Pichia pastoris [83], reaching a lycopene concentration of 1.2 and $4.7 \mathrm{mg} / \mathrm{g} \mathrm{dw}$, respectively. With the same genes used for C. utilis, the carotenoid pathway was also extended to astaxanthin in P. pastoris, but only $0.004 \mathrm{mg} / \mathrm{g} \mathrm{dw}$ were obtained [84].

Considerable progress has been made with metabolic engineering of Yarrowia lipolytica, including the establishment of carotenoid pathways [98]. First, application of CRISPR-Cas9 mediated integration of the bacterial carotenogenic genes: $c r t B$ for phytoene synthesis, and $c r t I$ for lycopene formation and enhancement of the terpenoid pathway by additional expression of the genes of $H M G$, phosphomevalonate kinate ERG8, and crtE led to the formation of $3.4 \mathrm{mg} / \mathrm{g} \mathrm{dw}$ lycopene [85]. Using a similar set of fungal genes except ERG8 and replacement of the phytoene synthase gene $c r t B$ by the bifunctional phytoene synthase/lycopene cyclase gene $\operatorname{crt} Y B$, all conventionally genome-integrated, the pathway was extended to $\beta$-carotene (Figure 7B), and a concentration of $12.5 \mathrm{mg} / \mathrm{g} \mathrm{dw}$ was obtained [86]. Additional integration of multi copies of a bacterial $\beta$-carotene hydroxylase gene crt $Z$ extended the pathway to zeaxanthin reaching $3.2 \mathrm{mg} / \mathrm{g} \mathrm{dw}$ of this carotenoid [87]. There is only one step left in the pathway to astaxanthin, which is carried out by a ketolase. By replacement of the bacterial crt $Z$ by an algal hydroxylase gene and the use of the algal $\beta$-carotene ketolase gene $b k t$, about half the synthesized carotenoids were converted to astaxanthin at a yield of $5.1 \mathrm{mg} / \mathrm{g} \mathrm{dw}$, as calculated from fermenter cultures [88].

Carotenogenic yeasts offer the advantage of an already existing terpenoid pathway, which is directed towards carotenoid biosynthesis and a carotenoid storage system. A $\beta$-carotene accumulating strain of Rhodotorula glutinis with enhanced pathway by overexpression of limiting and pathway genes including $\operatorname{crt} Y B$ (Figure 7C) resulted in a $\beta$ carotene yield of $27.1 \mathrm{mg} / \mathrm{g} \mathrm{dw}$ [89]. Of importance for the final step to $\beta$-carotene was the $\operatorname{crt} Y B$ gene. It favors the formation of bicyclic $\beta$-carotene over monocyclic $\gamma$-carotene, which is part of the competing pathway to torularhodin in R. glutinis [57]. A systematic genetic approach was accomplished to intervene with the astaxanthin biosynthesis pathway of $X$. denrorhous [99]. Starting from a high-yield astaxanthin mutant, the limiting steps were overcome by additional expression of the HMG, crtI, and $\operatorname{crt} Y B$ genes (Figure 7D). For more efficient $\beta$-carotene conversion to astaxanthin, transformation with additional copies of the astaxanthin synthase gene asy was effective. This led to a strain with $9.0 \mathrm{mg} / \mathrm{dw}$ astaxanthin [90]. The same engineering steps were applied to accumulate the intermediate phytoene by inactivation of the endogenous phytoene desaturase gene crtI (Figure 7D, arrow 1), yielding $7.5 \mathrm{mg} / \mathrm{g} \mathrm{dw}$ phytoene [91]. For the synthesis of zeaxanthin $\left(3,3^{\prime}\right.$ - 
dihydroxy- $\beta$-carotene), which is not part of the carotenoid pathway of $X$. denrorhous nor of any other fungus, asy was inactivated (Figure 7D, arrow 2) and the accumulated $\beta$-carotene converted to zeaxanthin with a bacterial $\beta$-carotene hydroxylase gene $\operatorname{crtZ}$ [92]. It was important to insert several copies of $c r t Z$ into the genome for substantial metabolization of $\beta$ carotene to zeaxanthin reaching up to $5.2 \mathrm{mg} / \mathrm{g} \mathrm{dw}$. X. denrorhous is also useful for building novel structures of carotenoid. By a combination of bacterial genes encoding $\beta$-carotene $2-$ hydroxylase, 3-hydroxylase, and 4-ketolase, the novel structures $2,2^{\prime}$-dihydroxy-4, $4^{\prime}$-diketozeaxanthin, and 2,2'-dihydroxy-4-monoketo-zeaxanthin were generated [100]. For further processing, both carotenoids were chemically reduced, resulting in 2,4,2' $4^{\prime}$-tetrahydroxyzeaxanthin and 2,4,2'-trihydroxy-zeaxanthin. The pathway engineering leading to these multioxy carotenoids can be regarded as a proof-of-concept demonstrating X. denrorhous as a synthesis platform was applicable for the biosynthesis of novel structures.

The carotenoid concentrations of the transformants in Figure 7 were obtained under routine laboratory conditions. Starting with a lipid overproducing strain of Y. lipolytica for transformation [101], optimized media and fed-batch fermentation procedures can increase the carotenoid concentrations considerably. For example, $16 \mathrm{mg} / \mathrm{g} \mathrm{dw}$ of lycopene [102] and $90 \mathrm{mg} / \mathrm{g} \mathrm{dw}$ of $\beta$-carotene [101] were reached in fermenter cultures of engineered Y. lipolytica, as well as $10.0 \mathrm{mg} / \mathrm{g} \mathrm{dw}$ phytoene [91] in fermenter culture of engineered $X$. denrorhous. Many yeast are able to grow on agricultural waste materials. For example, enhanced zeaxanthin synthesis was obtained with engineered $X$. denrorhous growing on wheat straw hemicellulose hydrolysate [92]. Furthermore, Y. lipolytica was improved by metabolic engineering to utilize of a wide range of substrates [103].

\subsection{Pathway Engineering of Saccharomyces Cerevisiae for High-Yield Carotenoid Formation}

Saccharomyces cerevisiae is an advanced system for metabolic pathway construction. Therefore, this yeast is not only a prominent system for establishing carotenoid pathways with similar genes used for other yeasts shown in Figure 7, but is also suitable to engineer around this pathway in order to boost the yields of the desired carotenoid. These combined approaches include modifications of the central metabolism for acetyl-CoA provision and modification of the lipid metabolism for increased carotenoid storage capacity [104].

In addition to the establishment of the lycopene pathway and the search for best possible gene combinations [105], the central metabolisms of S. cerevisiae were engineered to intensify the conversion of ethanol into acetyl-CoA [106,107] and to provide for a better NADPH supply $[105,106]$. Another target was the lipid metabolism. By overexpression of three genes of the pathway to triacylglycerols, lipid production was increased with a higher share of monoenic fatty acids due to a simultaneous overexpression of the desaturase gene OLE1 [106]. In combination with the inactivation of a regulator of lipid droplet size, the improved storage capacity corresponded to a higher accumulation of lycopene in fed-batch fermentation to a titer of $2.37 \mathrm{~g} / \mathrm{L}$ and a yield of $73.3 \mathrm{mg} / \mathrm{g} \mathrm{dw}$.

The development of a $\beta$-carotene producing $S$. cerevisiae is less advanced. A transformant carrying the genes from $X$. dendrorhous for $\beta$-carotene synthesis [108] was subjected to adaptive laboratory evolution in combination with oxidative stress and selection of hyperproducing mutants [109]. By sequencing their genomes, several mutations conferring $\mathrm{H}_{2} \mathrm{O}_{2}$ tolerance were identified, which were also accountable for higher $\beta$-carotene synthesis of up to $16.4 \mathrm{mg} / \mathrm{g} \mathrm{dw}$. A straightforward strategy for enhancing the carotenoid pathway is the adaptation of $S$. cerevisiae substrate utilization. Transformation with extracellular and cell-bound lipases enabled a $\beta$-carotene producing strain to grow on olive oil exclusively as a way to use olive mill waste as a substrate [110]. Supplementation of growth media with olive oil increased the lipid content of this strain. These lipids were able to provide a substantial supply of acetyl-CoA for carotenoid synthesis, which resulted in a $\beta$-carotene accumulation of $46.5 \mathrm{mg} / \mathrm{g} \mathrm{dw}$ and a titer of $477.9 \mathrm{mg} / \mathrm{L}$.

For the synthesis of astaxanthin from $\beta$-carotene, additional ketolation and hydroxylation steps are necessary. After screening for optimum ketolase and hydroxylase gene combinations, random mutagenesis resulted in a library including several mutants with 
increased astaxanthin formation [111]. For one of them with mutated CCS1 gene, transcriptional profiles indicated an impact on sterol biosynthesis. Higher formation of sterols may also suggest better metabolite supply for carotenogensis. In fermenter cultures of this mutant, the astaxanthin yield was $13.8 \mathrm{mg} / \mathrm{g} \mathrm{dw}$, accounting for a remarkable $89.4 \%$ of total carotenoids, and a titer of $0.22 \mathrm{mg} / \mathrm{L}$.

\section{Conclusions}

Fungi are of biotechnological interest as biotechnological production platforms for commercially important metabolites. Furthermore, they have a high potential for genetic pathway engineering. In fungi, special carotenoids of unique structures exist. For some of them, the biosynthesis pathways have been established by mutant analysis and functionality studies of the pathway genes. However, for the majority of fungal carotenoids, very little is known about the reaction sequences, the enzymes, and the genes involved in their biosynthesis. By comparison to well-known bacterial carotenogenic reactions, mechanisms for the insertion of oxy groups into carotenoid molecules were proposed. They may give a clue on the expected types of genes involved in fungal carotenogenesis and may be helpful for their identification in the future.

Metabolic engineering of carotenoid pathway especially in yeasts, either carotenogenic or non-carotenogenic, has made considerable progress in recent years. Combination of mutagenesis, adaptive laboratory evolution of carotenogenic lines, genetic engineering of the central carbon metabolism to enhance acetyl-CoA supply, and modification of the triacylglycerol lipid pathway to improve carotenoid storage capacity led to the construction of high-yield carotenoid-producing strains. Apart from mass produced $\beta$-carotene with $B$. trispora which already made it into the market, astaxanthin from engineered $X$. dendrorhous, with a content of almost $1 \%$ of cell mass in non-optimized laboratory cultures [90], can compete with astaxanthin from Haematococcus species, especially as it is accumulating in a non-esterified form [79]. Metabolic engineering of Y. lipolytica [87], and particularly $X$. dendrorhous [92], resulted in synthesis of the rare carotenoid zeaxanthin matching the concentrations of the high-yield mutant of Dunaliella salina [112].

Microorganisms such as yeasts offer the advantage of a controlled fermentation process. Development of advancing conditions for customized fermentation and application of selected substrates can make these transgenic yeasts attractive for commercial utilization. This includes production of carotenoids by growing on agroindustrial waste materials. This recycling process may work with the original strains or with those further engineered for the utilization of a specific substrate.

Funding: This research received no external funding.

Conflicts of Interest: The author declares no conflict of interest.

\section{Abbreviations}

$\begin{array}{ll}\text { CoA } & \text { coenzyme A } \\ \text { dw } & \text { dry weight } \\ \text { HMG } & \text { hydroxymethylglutaryl } \\ \text { NADPH } & \text { nicotinamide adenine dinucleotide phosphate }\end{array}$

\section{References}

1. Goodwin, T.W. The Biochemistry of the Carotenoids, 2nd ed.; Chapman and Hall: London, UK; New York, NY, USA, 1980; Volumn I, Chapter 8; pp. 257-290.

2. Valadon, L.R.G. Carotenoids as additional taxonomic characters in fungi: A review. Trans. Br. Mycol. Soc. 1976, 67, 1-15. [CrossRef]

3. Sandmann, G.; Misawa, N. Fungal carotenoids. In The Mycota X. Industrial Applications; Osiewacz, H.D., Ed.; Springer: Berlin, Germany, 2002; pp. 247-262.

4. Sandmann, G. Antioxidant protection from UV- and light-stress related to carotenoid structures. Antioxidants $2019,8,219$. [CrossRef] [PubMed] 
5. Will, O.H., III; Jankowski, P.; Kowacs, A.; Rossing, W.; Schneider, P.; Newland, N.A. A comparison of photo-killing among carotene and cytochrome $\mathrm{c}$ accumulating strains of the smut fungus Ustilaga violacea at specific wavelengths from 400 to $600 \mathrm{~nm}$. Photochem. Photobiol. 1987, 45, 609-615. [CrossRef]

6. Blanc, P.L.; Tuveson, R.W.; Sargent, M.L. Inactivation of carotenoid-producing and albino strains of Neurospora crassa by visible light, blacklight, and ultraviolet radiation. J. Bacteriol. 1976, 125, 616-625. [CrossRef] [PubMed]

7. Rau, W. Mechanism of photoregulation of carotenoid biosynthesis in plants. Pure Appl. Chem. 1985, 57, 777-784. [CrossRef]

8. Schimek, C.; Wöstemeyer, J. Carotene derivatives in sexual communication of zygomycete fungi. Phytochemistry 2009, 70, 1867-1875. [CrossRef]

9. Avalos, J.; Limón, M.C. Biological roles of fungal carotenoids. Curr. Genet. 2015, 61, 309-324. [CrossRef]

10. Braithwaite, G.D.; Goodwin, T.W. Studies in Carotenogenesis 26 . The incorporation of $[14 \mathrm{C}]$ acetate, $[14 \mathrm{C}]$ mevalonate and ${ }^{14} \mathrm{CO}_{2}$ into $\beta$-carotene by the fungus Phycomyces blakesleeanus. Biochem. J. 1960, 76, 5-10. [CrossRef]

11. Grob, C.; Butler, R. Über die Biosynthese des $\beta$-Carotins bei Mucor hiemalis Wehrner. Die Beteiligung der Essigsaure am Aufbau der Carotinmolekel, insbesondere in den Stellungen $3,4,6$ bzw. $3^{\prime}, 4^{\prime}, 6^{\prime}$, untersucht mit Hilfe von ${ }^{14}$ C-markierterEssigsäure. Helvet. Chim. Acta 1956, 39, 1775-1980. [CrossRef]

12. Lee, T.C.; Chichester, C.O. Geranylgeranyl pyrophosphate as the condensing unit for enzymatic synthesis of carotenes. Phytochemistry 1969, 8, 603-609. [CrossRef]

13. Bramley, P.M.; Davies, B. Carotene biosynthesis by cell extracts of mutants of Phycomyces blakesleeanus. Phytochemistry 1975, 14, 463-469. [CrossRef]

14. Eme, L.; Spang, A.; Lombard, J.; Stairs, C.W.; Ettema, T.J.G. Archaea and the origin of eukaryotes. Nat. Rev. Microbiol. 2017, 15, 711-723. [CrossRef] [PubMed]

15. Peck, R.F.; Johnson, E.A.; Krebs, M.P. Identification of a lycopene beta-cyclase required for bacteriorhodopsin biogenesis in the archaeon Halobacterium salinarum. J. Bacteriol. 2002, 184, 2889-2897. [CrossRef] [PubMed]

16. Verdoes, J.C.; Krubasik, P.; Sandmann, G.; van Ooyen, A.J.J. Isolation and functional characterisation of a novel type of carotenoid biosynthetic gene from Xanthophyllomyces dendrorhous. Mol. Gen. Genet. 1999, 262, 453-461. [CrossRef] [PubMed]

17. Hemmi, H.; Ikejiri, S.; Nakayama, T.; Nishino, T. Fusion-type lycopene $\beta$-cyclase from a thermoacidophilic archaeon Sulfolobus solfataricus. Biochem. Biophys. Res. Commun. 2003, 305, 586-591. [CrossRef]

18. Lombard, J.; Moreira, D. Origins and early evolution of the mevalonate pathway of isoprenoid biosynthesis in the three domains of life. Mol. Biol. Evol. 2011, 28, 87-99. [CrossRef]

19. Lange, B.M.; Rujan, T.; Martin, W.; Croteau, R. Isoprenoid biosynthesis: The evolution of two ancient and distinct pathways across genomes. Proc. Natl. Acad. Sci. USA 2000, 97, 13172-13177. [CrossRef]

20. Almeida, E.R.A.; Cerdá-Olmedo, E. Gene expression in the regulation of carotene biosynthesis in Phycomyces. Curr. Genet. 2008, 53, 129-137. [CrossRef]

21. Moran, N.A.; Jarvik, T. Lateral transfer of genes from fungi underlies carotenoid production in aphids. Science 2010, 328, 624-627. [CrossRef]

22. Schmidhauser, T.J.; Lauter, F.R.; Schumacher, M.; Zhou, W.; Russo, V.E.; Yanofsky, C. Characterization of al-2, the phytoene synthase gene of Neurospora crassa. Cloning, sequence analysis, and photoregulation. J. Biol. Chem. 1994, 269, 12060-12066. [CrossRef]

23. Avalos, J.; Pardo-Medina, J.; Parra-Rivero, O.; Ruger-Herreros, M.; Rodríguez-Ortiz, R.; Hornero-Méndez, D.; Limón, M.C.J. Carotenoid biosynthesis in Fusarium. J. Fungi 2017, 3, 39. [CrossRef] [PubMed]

24. Schmidhauser, T.J.; Lauter, F.R.; Russo, V.E.; Yanofsky, C. Cloning, sequence, and photoregulation of al-1, a carotenoid biosynthetic gene. Mol. Cell. Biol. 1990, 10, 5064-5070. [PubMed]

25. Verdoes, J.C.; Misawa, N.; van Ooyen, A.J. Cloning and characterization of the astaxanthin biosynthetic gene encoding phytoene desaturase of Xanthophyllomyces dendrorhous. Biotechnol. Bioeng. 1999, 63, 750-755. [CrossRef]

26. Breitenbach, J.; Fraser, P.D.; Sandmann, G. Carotenoid synthesis and phytoene synthase activity during mating of Blakeslea trispora. Phytochemistry 2012, 76, 40-45. [CrossRef]

27. Ruiz-Hidalgo, M.R.; Benito, E.P.; Sandmann, G.; Eslava, A.P. The phytoene dehydrogenase gene of Phycomyces: Regulation of its expression by blue light and vitamin A. Mol. Gen. Gent. 1997, 253, 734-744. [CrossRef]

28. Hausmann, A.; Sandmann, G. A single five-step desaturase is involved in the carotenoid biosynthesis pathway to $\gamma$-carotene and torulene in Neurospora crassa. Fungal Genet. Biol. 2000, 30, 147-153. [CrossRef]

29. Aasen, A.J.; Jensen, S.L. Fungal carotenoids II. The structure of the carotenoid acid neurosporaxanthin. Acta Chem. Scand. 1965, 19, 1843-1853. [CrossRef]

30. Goldie, A.H.; Subden, R.E. The neutral carotenoids of wild-type and mutant strains of Neurospora crassa. Biochem. Genet. 1973, 10, 275-284. [CrossRef]

31. Sandmann, G.; Takaichi, S.; Fraser, P.D. Novel C35-apocarotenoids in the yellow mutant Neurospora crassa YLO. Phytochemistry 2008, 69, 2886-2890. [CrossRef]

32. Estrada, A.F.; Youssar, L.; Scherzinger, D.; Al-Babili, S.; Avalos, J. The ylo-1 gene encodes an aldehyde dehydrogenase responsible for the last reaction in the Neurospora carotenoid pathway. Mol. Microbiol. 2008, 69, 1207-1220. [CrossRef]

33. Saelices, L.; Youssar, L.; Holdermann, I.; Al-Babili, S.; Avalos, J. Identification of the gene responsible for torulene cleavage in the Neurospora carotenoid pathway. Mol. Genet. Genom. 2007, 278, 527-537. [CrossRef] [PubMed] 
34. Prado-Cabrero, A.; Estrada, A.F.; Al-Babili, S.; Avalos, J. Identification and biochemical characterization of a novel carotenoid oxygenase: Elucidation of the cleavage step in the Fusarium carotenoid pathway. Mol. Microbiol. 2007, 64, 448-460. [CrossRef] [PubMed]

35. Díaz-Sánchez, V.; Estrada, A.F.; Trautmann, D.; Al-Babili, S.; Avalos, J. The gene carD encodes the aldehyde dehydrogenase responsible for neurosporaxanthin biosynthesis in Fusarium fujikuroi. FEBS J. 2011, 278, 3164-3176. [CrossRef]

36. Jin, J.-M.; Lee, J.; Lee, Y.-W. Characterization of carotenoid biosynthetic genes in the ascomycete Gibberella zeae. FEMS Microbiol. Lett. 2010, 302, 197-202. [CrossRef] [PubMed]

37. Strobel, I.; Breitenbach, J.; Scheckhuber, C.Q.; Osiewacz, H.D.; Sandmann, G. Carotenoids and carotenogenic genes in Podospora anserina: Engineering of the carotenoid composition extends the life span of the mycelium. Curr. Genet. 2009, 55, 175-184. [CrossRef] [PubMed]

38. Andrewes, A.G.; Phaff, H.J.; Starr, M.P. Carotenoids of Phaffia rhodozyma, a red-pigmented fermenting yeast. Phytochemistry 1976, 15, 1003-1007. [CrossRef]

39. Andrewes, A.G.; Starr, M.P. (3R,30R)-Astaxanthin from the yeast Phaffia rhodozyma. Phytochemistry 1976, 15, 1009-1011. [CrossRef]

40. Ojima, K.; Breitenbach, J.; Visser, H.; Setoguchi, Y.; Tabata, K.; Hoshino, T.; van den Berg, J.; Sandmann, G. Cloning of the astaxanthin synthase gene from Xanthophyllomyces dendrorhous (Phaffia rhodozyma) and its assignment as a $\beta$-carotene 3hydroxylase/4-ketolase. Mol. Genet. Genom. 2006, 275, 148-158. [CrossRef]

41. Alvarez, V.; Rodríguez-Sáiz, M.; de la Fuente, J.L.; Gudiña, E.J.; Godio, R.P.; Martín, J.F.; Barredo, J.L. The crtS gene of Xanthophyllomyces dendrorhous encodes a novel cytochrome-P450 hydroxylase involved in the conversion of $\beta$-carotene into astaxanthin and other xanthophylls. Fungal Genet. Biol. 2006, 43, 261-272. [CrossRef]

42. Alcaíno, J.; Barahona, S.; Carmona, M.; Lozano, C.; Marcoleta, A.; Niklitschek, M.; Sepúlveda, D.; Baeza, M.; Cifuentes, V. Cloning of the cytochrome $\mathrm{p} 450$ reductase (crtR) gene and its involvement in the astaxanthin biosynthesis of Xanthophyllomyces dendrorhous. BMC Microbiol. 2008, 8, 169. [CrossRef]

43. Verdoes, J.C.; Sandmann, G.; Visser, H.; Diaz, M.; van Mossel, M.; van Ooyen, A.J.J. Metabolic engineering of the carotenoid biosynthetic pathway in the yeast Xanthophyllomyces dendrorhous (Phaffia rhodozyma). Appl.Environ. Microbiol. 2003, 69, 3728-3738. [CrossRef] [PubMed]

44. Vazquez, M.; Santos, V. 3-Hydroxy-3', 4'-didehydro-beta- $\psi$-caroten-4-one (HDCO) from Xanthophyllomyces dendrorhous (Phaffia rhodozyma) cultivated on xylose media. Biotechnol. Lett. 1998, 20, 181-182. [CrossRef]

45. Schrantz, J.P.; Lemoine, Y. Carotenoid composition of mycelium and apothecia in the discomycete Scutellinia umbrarum. Phytochemistry 1995, 40, 33-35. [CrossRef]

46. Madhour, A.; Anke, H.; Mucci, A.; Davoli, P.; Weber, R.W.S. Biosynthesis of the xanthophyll plectaniaxanthin as a stress response in the red yeast Dioszegia (Tremellales, Heterobasidiomycetes, Fungi). Phytochemistry 2005, 66, 2617-2626. [CrossRef] [PubMed]

47. Davoli, P.; Mierau, V.; Weber, R.W.S. Carotenoids and fatty acids in red yeasts Sporobolomyces roseus and Rhodotorula glutinis. Appl. Biochem. Microbiol. 2004, 40, 392-397. [CrossRef]

48. Valadon, L.R.G. Carotenoid pigments of Protomyces inundates, Dangerard. Phytochemistry 1963, 2, 71-73. [CrossRef]

49. Lederer, E. Sur les carotenoides des cryptogames. Bull. Soc. Chim. Fr. 1938, 20, 611-634.

50. Smits, B.L.; Peterson, W.J. Carotenoids of telia galls of Gymnosporangium juniperi-virginianae LK. Science 1942, 96, $210-211$. [CrossRef]

51. Haxo, F. Carotenoids of the mushroom Cantharellus cinnabarinus. Bot. Gaz. 1950, 112, 228-232. [CrossRef]

52. Arpin, N.; Kj $\varphi s e n$, H.; Francis, G.W.; Liaaen-Jensen, S. The structure of aleuriaxanthin. Phytochemistry 1973, 12, $2751-2758$. [CrossRef]

53. Arpin, N.; Liaaen-Jensen, S. Recherches chimotaxinomiques sur les champignons. Fungal carotenoids. III-Nouveaux carotenoides, notamment sous forme d'esters tertiaires, isoles de Plectania coccinea (Scop. Ex Fr) Fuck. Phytochemistry 1967, 6, 995-1005. [CrossRef]

54. Molnár, P.; Ösz, E.; Turcsi, E.; Delia, J. Carotenoid composition of the mushroom Scarlet elf cup (Sarcoscypha coccinea). Heliyon 2019, 5, e01883. [CrossRef] [PubMed]

55. Bae, M.; Lee, T.H.; Yokoyama, H.; Böttger, H.G.; Chichester, C.O. The occurrence of plectaniaxanthin in Cryptococcus laurentii. Phytochemistry 1971, 10, 625-629. [CrossRef]

56. Arpin, N.; Liaaen-Jensen, S. Recherches chimiotaxinomiques sur le champignons. Sur la présence de l'ester méthylique de la torularhodine chez Cookeina sulcipes. C. R. Acad. Sci. Paris 1967, 265, 1083-1085.

57. Herz, S.; Weber, R.W.S.; Anke, H.; Mucci, A.; Davoli, P. Intermediates in the oxidative pathway from torulene to torularhodin in the red yeasts Cystofilobasidium infirmominiatum and C. capitatum (Heterobasidiomycetes, Fungi). Phytochemistry 2007, 68, 2503-2511. [CrossRef]

58. Fraser, P.D.; Miura, Y.; Misawa, N. In vitro characterization of astaxanthin biosynthetic enzymes. J. Biol. Chem. 1997, 272, 6128-6135. [CrossRef]

59. Breitenbach, J.; Gerjets, T.; Sandmann, G. Catalytic properties and reaction mechanism of the CrtO carotenoid ketolase from the cyanobacterium Synechocystis sp. PCC 6803. Arch. Biochem. Biophys. 2013, 529, 86-91. [CrossRef]

60. Takaichi, S.; Jung, D.O.; Madigan, M.T. Accumulation of unusual carotenoids in the spheroidene pathway, demethylspheroidene and demethylspheroidenone, in an alkaliphilic purple nonsulfur bacterium Rhodobaca bogoriensis. Photosynth. Res. 2001, 67, 207-214. [CrossRef] 
61. Steiger, S.; Mazet, A.; Sandmann, G. Heterologous expression, purification, and enzymatic characterization of the acyclic carotenoid 1,2-hydratase from Rubrivivax gelatinosus. Arch. Biochem. Biophys. 2003, 414, 51-58. [CrossRef]

62. Albrecht, M.; Ruther, A.; Sandmann, G. Purification and biochemical characterization of a hydroxyneursporene desaturase involved in the biosynthetic pathway of the carotenoid spheroidene in Rhodobacter spheroides. J. Bacteriol. 1997, 179, $7462-7467$. [CrossRef]

63. Gerjets, T.; Steiger, S.; Sandmann, G. Catalytic properties of the expressed acyclic carotenoid 2-ketolases from Rhodobacter capsulatus and Rubrivivax gelatinosus. Biochim. Biophys. Acta. 2009, 1791, 125-131. [CrossRef] [PubMed]

64. Graham, J.E.; Bryant, D.A. The biosynthetic pathway for myxol-2' fucoside (myxoxanthophyll) in the cyanobacterium Synechococcus sp. strain PCC 7002. J. Bacteriol. 2009, 191, 3292-3300. [CrossRef] [PubMed]

65. Steiger, S.; Perez-Fons, L.; Cutting, S.M.; Fraser, P.D.; Sandmann, G. Annotation and functional assignment of the genes for the C30 carotenoid pathways from the genomes of two bacteria Bacillus indicus and Bacillus firmus. Microbiology 2015, 161, 194-202. [CrossRef] [PubMed]

66. Sandmann, G. Diversity and origin of carotenoid biosynthesis: Its history of coevolution towards plant photosynthesis. New Phytol. 2021, 232, 479-493. [CrossRef]

67. Fitzpatrick, D.A. Horizontal gene transfer in fungi. FEMS Microbiol. Lett. 2012, 329, 1-8. [CrossRef]

68. Gooday, D.W.; Carlile, M.J. The discovery of fungal sex hormones. III. Trisporic acid and its precorsors. Mcologist 1997, 11, 126-130. [CrossRef]

69. Barreroa, A.F.; Herrador, M.M.; Arteaga, J.F.; González-Delgado, J.A. Occurrence and chemical synthesis of apocarotenoids from Mucorales: A review. Nat. Prod. Commun. 2017, 12, 733-741. [CrossRef]

70. Sutter, R.P.; Capage, D.A.; Harrison, T.L.; Keen, W.A. Trisporic acid biosynthesis in separate plus and minus cultures of Blakeslea trispora: Identification by Mucor assay of two mating-type-specific components. J. Bacteriol. 1973, 114, 1074-1082. [CrossRef]

71. Ahrazem, O.; Gómez-Gómez, L.; Rodrigo, M.R.; Avalos, J.; Limón, M.C. Carotenoid cleavage oxygenases from microbes and photosynthetic organisms: Features and functions. Int. J. Mol. Sci. 2016, 17, 1781. [CrossRef]

72. Burmester, A.; Richter, M.; Schultze, K.; Voelz, K.; Schachtschabel, D.; Boland, W.; Wöstemeyer, J.; Schimek, C. Cleavage of $\beta$-carotene as the first step in sexual hormone synthesis in zygomycetes is mediated by a trisporic acid regulated $\beta$-carotene oxygenase. Fungal Genet. Biol. 2007, 44, 1096-1108. [CrossRef]

73. Medina, H.R.; Cerdá-Olmedo, E.; Al-Babili, S. Cleavage oxygenases for the biosynthesis of trisporoids and other apocarotenoids in Phycomyces. Mol. Microbiol. 2011, 82, 199-208. [CrossRef] [PubMed]

74. Lee, S.C.; Heitman, J. Sex in the Mucoralean fungi. Mycoses 2014, 57, 18-24. [CrossRef] [PubMed]

75. Wetzel, J.; Scheibner, O.; Burmester, A.; Schimek, C.; Wöstemeyer, J. 4-Dihydrotrisporin-dehydrogenase, an enzyme of the sex hormone pathway of Mucor mucedo: Purification, cloning of the corresponding gene, and developmental expression. Eukaryot. Cell 2009, 8, 88-95. [CrossRef] [PubMed]

76. Schachtschabel, D.; David, A.; Menzel, K.-D.; Schimek, C.; Wöstemeyer, J.; Boland, W. Cooperative biosynthesis of trisporoids by the (+) and (-) mating types of the zygomycete Blakeslea trispora. ChemBioChem 2008, 9, 3004-3012. [CrossRef] [PubMed]

77. Czempinski, K.; Kruft, V.; Wöstemeyer, J.; Burmester, A. 4- Dihydromethyltrisporate dehydrogenase from Mucor mucedo, an enzyme of the sexual hormone pathway: Purification, and cloning of the corresponding gene. Microbiology 1966, 142, 2647-2654. [CrossRef] [PubMed]

78. Werkman, B. Localization and partial characterization of a sex-specific enzyme in homothallic and heterothallic Mucorales. Arch. Microbiol. 1976, 109, 209-213. [CrossRef]

79. Sandmann, G. Carotenoids of biotechnological importance. In Biotechnology of Isoprenoids, Advances in Biochemical Engineering/Biotechnology; Schrader, J., Bohlmann, J., Eds.; Springer: Berlin/Heidelberg, Germany, 2014; Volume 148, pp. $449-467$.

80. Kanamoto, H.; Nakamura, K.; Misawa, N. Carotenoid production in oleaginous yeasts. Adv. Exp. Med. Biol. 2021, 1261, 153-163

81. Miura, Y.; Kondo, K.; Saito, T.; Shimada, H.; Fraser, P.D.; Misawa, N. Production of the carotenoids lycopene, B-carotene, and astaxanthin in the food yeast Candida utilis. Appl. Environ. Microbiol. 1998, 64, 1226-1229. [CrossRef]

82. Shimada, H.; Kondo, K.; Fraser, P.D.; Miura, Y.; Saito, T.; Misawa, N. Increased carotenoid production by the food yeast Candida utilis through metabolic engineering of the isoprenoid pathway. Appl. Environ. Microbiol. 1998, 64, 2676-2680. [CrossRef]

83. Bhataya, A.; Schmidt-Dannert, C.; Lee, P.C. Metabolic engineering of Pichia pastoris X-33 for lycopene production. Process. Biochem. 2009, 44, 1095-1102. [CrossRef]

84. Araya-Garay, J.M.; Ageitos, J.M.; Vallejo, J.A.; Veiga-Crespo, P.; Sánchez-Pérez, A.; Villa, T.G. Construction of a novel Pichia pastoris strain for production of xanthophylls. AMB Express 2012, 2, 24. [CrossRef] [PubMed]

85. Schwartz, C.; Shabbir-Hussain, M.; Frogue, K.; Blenner, M.; Wheeldon, I. Standardized markerless gene integration for pathway engineering in Yarrowia lipolytica. ACS Synth. Biol. 2017, 6, 402-409. [CrossRef] [PubMed]

86. Liu, L.; Qu, Y.L.; Dong, G.R.; Wang, J.; Hu, C.Y.; Meng, Y.H. Elevated $\beta$-carotene production using codon-adapted CarRA\&B and metabolic balance in engineered Yarrowia lipolytica. Front. Microbiol. 2021, 12, 627150. [PubMed]

87. Xie, Y.; Chen, S.; Xiong, X. Metabolic engineering of non-carotenoid-producing yeast Yarrowia lipolytica for the biosynthesis of zeaxanthin. Front. Microbiol. 2021, 12, 699235. [CrossRef] [PubMed]

88. Tramontin, L.R.R.; Kildegaard, K.R.; Sudarsan, S.; Borodina, I. Enhancement of astaxanthin biosynthesis in oleaginous yeast Yarrowia lipolytica via microalgal pathway. Microorganisms 2019, 7, 472. [CrossRef] 
89. Pi, H.-W.; Anandharaj, M.; Kao, Y.-Y.; Lin, Y.-J.; Chang, J.-J.; Li, W.-H. Engineering the oleaginous red yeast Rhodotorula glutinis for simultaneous $\beta$-carotene and cellulase production. Sci. Rep. 2018, 8, 10850. [CrossRef]

90. Gassel, S.; Breitenbach, J.; Sandmann, G. Genetic engineering of the complete carotenoid pathway towards enhanced astaxanthin formation in Xanthophyllomyces dendrorhous starting from a high-yield mutant. Appl. Microbiol. Biotechnol. 2014, 98, 345-350. [CrossRef]

91. Pollmann, H.; Breitenbach, J.; Sandmann, G. Development of Xanthophyllomyces dendrorhous as a production system for the colorless carotene phytoene. J. Biotechnol. 2017, 247, 34-41. [CrossRef]

92. Breitenbach, J.; Pollmann, H.; Sandmann, G. Genetic modification of the carotenoid pathway in the red yeast Xanthophyllomyces dendrorhous: Engineering of a high-yield zeaxanthin strain. J. Biotechnol. 2019, 289, 112-117. [CrossRef]

93. Salgado, L.; Bejarano, E.R.; Cerda-Olmedo, W. Carotene-superproducing mutants of Phycomyces blakesleeanus. Exp. Mycol. 1989, 13, 332-336. [CrossRef]

94. Avalos, J.; Cerdá-Olmedo, E. Carotenoid mutants of Gibberella fujikuroi. Curr. Genet. 1987, 25, 1837-1841. [CrossRef]

95. Schmidt, I.; Schewe, H.; Gassel, S.; Jin, C.; Buckingham, J.; Hümbelin, M.; Sandmann, G.; Schrader, J. Biotechnological production of astaxanthin with Phaffia rhodozyma/Xanthophyllomyces dendrorhous. Appl. Microbiol. Biotechnol. 2010, 8, 555-571. [CrossRef] [PubMed]

96. Gassel, S.; Schewe, H.; Schmidt, I.; Schrader, J.; Sandmann, G. Multiple improvement of astaxanthin biosynthesis in Xanthophyllomyces dendrorhous by a combination of conventional mutagenesis and metabolic pathway engineering. Biotechnol. Lett. 2013, 35, 565-569. [CrossRef] [PubMed]

97. Mehta, B.J.; Obraztsova, I.N.; Cerdá-Olmedo, E. Mutants and intersexual heterokaryons of Blakeslea trispora for production of $\beta$-carotene and lycopene. Appl. Environ. Microbiol. 2003, 69, 4043-4048. [CrossRef] [PubMed]

98. Mawgoud, A.M.; Markham, K.A.; Palmer, C.M.; Liu, N.; Stephanopoulos, G.; Alper, H.S. Metabolic engineering in the host Yarrowia lipolytica. Metab. Eng. 2018, 50, 192-208. [CrossRef]

99. Sandmann, G.; Pollmann, H.; Gassel, S.; Breitenbach, J. Xanthophyllomyces dendrorhous, a versatile platform for the production of carotenoids and other acetyl-CoA-derived compounds. J. Adv. Exp. Med. Biol. 2021, 1261, 137-151.

100. Pollmann, H.; Breitenbach, J.; Wolff, H.; Bode, H.B.; Sandmann, G. Combinatorial biosynthesis of novel multi-hydroxy carotenoids in the red yeast Xanthophyllomyces dendrorhous. J. Fungi 2017, 3, 9. [CrossRef]

101. Larroude, M.; Celinska, E.; Back, A.; Thomas, S.; Nicaud, J.-M.; Ledesma-Amaro, R. A synthetic biology approach to transform Yarrowia lipolytica into a competitive biotechnological producer of $\beta$-carotene. Biotechnol. Bioeng. 2017, 115, 464-472. [CrossRef]

102. Matthäus, F.; Ketelhot, M.; Gatter, M.; Barth, G. Production of lycopene in the non-carotenoid-producing yeast Yarrowia lipolytica. Appl. Environ. Microbiol. 2014, 80, 1660-1669. [CrossRef]

103. Spagnuolo, M.; Hussain, M.S.; Gambill, L.; Blenner, M. Alternative substrate metabolism in Yarrowia lipolytica. Front. Microbiol. 2018, 9, 1077. [CrossRef]

104. Li, C.; Swofford, C.A.; Sinskey, A.J. Modular engineering for microbial production of carotenoids. Metab. Eng. Commun. 2020, 10, e00118. [CrossRef] [PubMed]

105. Shi, B.; Ma, T.; Ye, Z.; Li, X.; Huang, Y.; Zhou, Z.; Ding, Y.; Deng, Z.; Liu, T. Systematic metabolic engineering of Saccharomyces cerevisiae for lycopene overproduction. J. Agric. Food Chem. 2019, 67, 11148-11157. [CrossRef] [PubMed]

106. Ma, T.; Shi, S.; Ye, Z.; Li, X.; Liu, M.; Chen, Y.; Xia, J.; Nielsen, J.; Deng, Z.; Liu, T. Lipid engineering combined with systematic metabolic engineering of Saccharomyces cerevisiae for high-yield production of lycopene. Metab. Eng. 2019, 52, 134-142. [CrossRef] [PubMed]

107. Chen, Y.; Xiao, W.; Wang, Y.; Liu, H.; Li, X.; Yuan, Y. Lycopene overproduction in Saccharomyces cerevisiae through combining pathway engineering with host engineering. Microb. Cell Fact. 2016, 15, 113. [CrossRef]

108. Verwaal, R.; Wang, J.; Meijnen, J.-P.; Visser, H.; Sandmann, G.; van den Berg, J.A.; van Ooyen, J.J. High-level production of betacarotene in Saccharomyces cerevisiae by successive transformation with carotenogenic genes from Xanthophyllomyces dendrorhous. Appl. Environ. Microbiol. 2007, 73, 4342-4350. [CrossRef]

109. Godara, A.; Gomez-Rodriguez, M.A.; Weatherston, J.D.; Peabody, G.L.; Wu, H.-J.; Kao, K.C. Beneficial mutations for carotenoid production identified from laboratory-evolved Saccharomyces cerevisiae. J. Ind. Microbiol. Biotechnol. 2019, 46, 1793-1804. [CrossRef]

110. Fathi, Z.; Tramontin, L.R.R.; Ebrahimipour, G.; Borodina, I.; Darvishi, F. Metabolic engineering of Saccharomyces cerevisiae for production of $\beta$-carotene from hydrophobic substrates. FEMS Yeast Res. 2021, 21, foaa068. [CrossRef]

111. Jin, J.; Wang, Y.; Yao, M.; Gu, X.; Li, B.; Liu, H.; Ding, M.; Xiao, W.; Yuan, Y. Astaxanthin overproduction in yeast by strain engineering and new gene target uncovering. Biotechnol. Biofuels 2018, 11, 230. [CrossRef]

112. Jin, E.; Feth, B.; Melis, A. A mutant of the green alga Dunaliella salina constitutively accumulates zeaxanthin under all growth conditions. Biotechnol. Bioeng. Symp. 2003, 81, 115-124. [CrossRef] 